\title{
Life cycle assessment of residual forestry biomass chips at a power plant: a Portuguese case study
}

\author{
José V. Ferreira $\cdot$ Helder Viana $\cdot$ Bruno Esteves $\cdot$ \\ Luísa P. Cruz Lopes · Idalina Domingos
}

Received: 27 July 2013/Accepted: 10 January 2014/Published online: 1 April 2014

(C) The Author(s) 2014. This article is published with open access at Springerlink.com

\begin{abstract}
The residual forest biomass (RFB) sector has been experiencing strong development at European level and particularly in Portugal mainly due to the increase of energy production from renewable sources. The aim of this study is to assess the environmental impacts of eucalyptus RFB chips production chain in Portugal. The environmental and economic impact comparison of the processes included in the production chain is presented as well. The environmental impacts were calculated by the life cycle assessment approach described in the ISO 14040 series of standards. The production chain assessed included all processes from eucalyptus forest until the delivery of RFB chips at the power plant. The main conclusion of this study is that eucalyptus wood production is the process that presents the greatest environmental impact through the product life cycle. Considering only emissions and depletion of energy resources, RFB chipping is the process that presents the higher environmental impact followed by transport of RFB by truck and trailer and transport of RFB by forwarder. These operations are responsible for approximately $81 \%$ on "Respiratory inorganic" and $87 \%$ on "Fossil fuels" which are the two most significant normalized impact categories. In economic terms, the transport of RFB by truck and trailer presents the highest cost followed by chipping and processing of trees. These three operations are responsible for approximately $80 \%$ of total
\end{abstract}

5th International Congress on Energy and Environmental Engineering and Management (CIIEM).

J. V. Ferreira $(\varangle) \cdot$ H. Viana $\cdot$ B. Esteves .

L. P. Cruz Lopes · I. Domingos

Centro de Estudos em Educação, Tecnologia e Saúde, ESTGV, Instituto Politécnico de Viseu, Campus Politécnico de Repeses, 3504-510 Viseu, Portugal

e-mail: jvf@estv.ipv.pt costs. A sensitivity analysis showed that a $32 \%$ increase in the transport distance from the forest to the power plant would cause an $8 \%$ increase in "Climate change".

Keywords Forestry - Life cycle assessment - Renewable energy $\cdot$ Residual forestry biomass · Wood energy

\section{Introduction}

The sustainable use of residual forestry biomass (RFB) (branches and tops) to produce electricity and heat is a good alternative to the use of fossil fuels because its burn is neutral in terms of $\mathrm{CO}_{2}$ emissions into the atmosphere and thus contributes toward reducing global warming.

To reduce greenhouse gas emissions within the Community and comply with the Kyoto Protocol to the United Nations Framework Convention on Climate Change, and with further Community and international greenhouse gas emission reduction commitments, and reduce its dependence on energy imports, the European Community approved the Directive 2009/28/EC [1] on the promotion of the use of energy from renewable sources. According to Annex I of this Directive, Portugal shall ensure that the share of energy from renewable sources in gross final consumption of energy in 2020 is at least $31 \%$. Such mandatory national overall targets are consistent with a target of at least a $20 \%$ share of energy from renewable sources in the Community's gross final consumption of energy in 2020.

To be able to achieve the national objectives set out in this Annex, in recent years, several power plants were built in Portugal whose fuel is RFB. According to the statistical data [2], the total installed power in biomass power plants (without cogeneration) increased from $24 \mathrm{MW}$ in 2008 to 


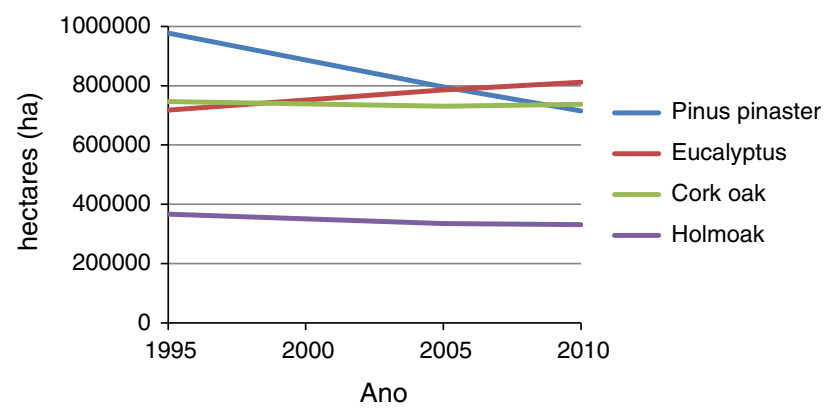

Fig. 1 Evolution of forest land use of the main species in Portugal (adapted from [3])

$105 \mathrm{MW}$ in 2012 which corresponded to an increase in the production of electrical energy of 146-718 GWh, respectively. In 2012, the electrical energy produced through biomass represented more than $12 \%$ of the electric energy produced through renewable energy sources. The RFB sector for energy has been experiencing strong development with increasing production of electricity nationwide and plays an important role in the framework of the Directive 2009/28/EC. It is expected that the increase in collection of RFB, which was previously kept in the forest, can contribute in the future to the reduction of forest fires that have plagued the country in recent years.

Forest land use represents the dominant land use in Continental Portugal, occupying 3,154,800 ha (in 2010), representing $35.4 \%$ of the territory [3]. Eucalyptus (Eucalyptus globulus) is the main species produced in Portugal with the largest planted area $(811,943 \mathrm{ha}$ ) (about $26 \%$ of the total forest area). It is the species which has grown more since 1995 mainly at the expense of maritime pine area, as shown in Fig. 1.

According to Netto [4], the annual production of eucalyptus RFB in Continental Portugal is between $1.2 \mathrm{t}(\mathrm{dm}) /$ ha year (optimistic scenario) and $1.08 \mathrm{t}(\mathrm{dm}) / \mathrm{ha}$ year (conservative scenario), i.e., on average $1.11 \mathrm{t}(\mathrm{dm}) /$ ha year. In the study of forest energy crops [5], the authors estimate that the current biomass consumption $(2.0 \mathrm{Mt} /$ year) is close to the supply of residual biomass (2.0-2.5 Mt/year), and citing [6], $1.1 \mathrm{Mt} /$ year are eucalyptus and $1.41 \mathrm{Mt} / \mathrm{year}$ are pine. They also estimate that the short-term needs of raw materials for wood energy industry will be about $4.5 \mathrm{Mt} / \mathrm{year}$.

Aware of the development of the forest biomass sector for energy purposes, the Biomass Center for Energy studied the logging operations, collection, packaging, transportation and primary processing of RFB for energy production to assess the financial costs [7], but it did not evaluate the environmental impacts each process causes in the environment.

As environmental awareness increases, industries and businesses have started to assess how their activities affect the environment. Life cycle assessment (LCA) is the best Environmental System Analysis tool to evaluate the environmental burdens associated with a product, process, or activity by: compiling an inventory of relevant energy and material inputs and environmental releases; evaluating the potential environmental impacts associated with identified inputs and releases; and, interpreting the results to help make a more informed decision [8].

Previous studies [9-11] aiming at evaluating the environmental performance of wood production for energy purposes have been carried out but none of them in Portugal. The studies have revealed large differences in environmental impact caused by forestry operations, mainly due to differences in location and forestry practice. Therefore, there was an obvious need for a study on environmental performance for forestry operations in Portugal.

The purpose of this study is to assess the environmental impact from forestry operations in the central region of Portugal and identify needs and options for environmental improvements in the RFB chips production chain. With this study, the authors intend to provide those interested in the industry of RFB for energy purposes additional information that can complement the studies prepared by the Biomass Center for Energy mentioned before. For the previously cited reasons, it is not the objective of this study the comparison of results in international terms.

\section{Methods}

To evaluate the environmental aspects and potential impacts associated with the product and processes, a LCA study was performed based on the ISO 14040/44:2006 series of standards recommendation methodology (International Organization for Standardization) [12].

According to ISO 14040/44:2006 series of standards, LCA is divided into four phases: (1) goal definitionwhich defines the aim and scope of the study as well as the functional unit; (2) inventory analysis-which lists emissions of pollutants into air, water and soil, solid wastes and consumption of resources per functional unit; (3) impact assessment-which assesses the environmental impact of the pollutants emitted throughout the life cycle; (4) interpretation of results. Despite their apparent simplicity, however, LCA profiles are not so easily interpreted. Normalization makes it possible to translate abstract impact scores for every impact category into relative contributions of the product to a reference situation. This reference situation consists in an environmental profile of an economic system that the product life cycle is considered to be part of [13]. 


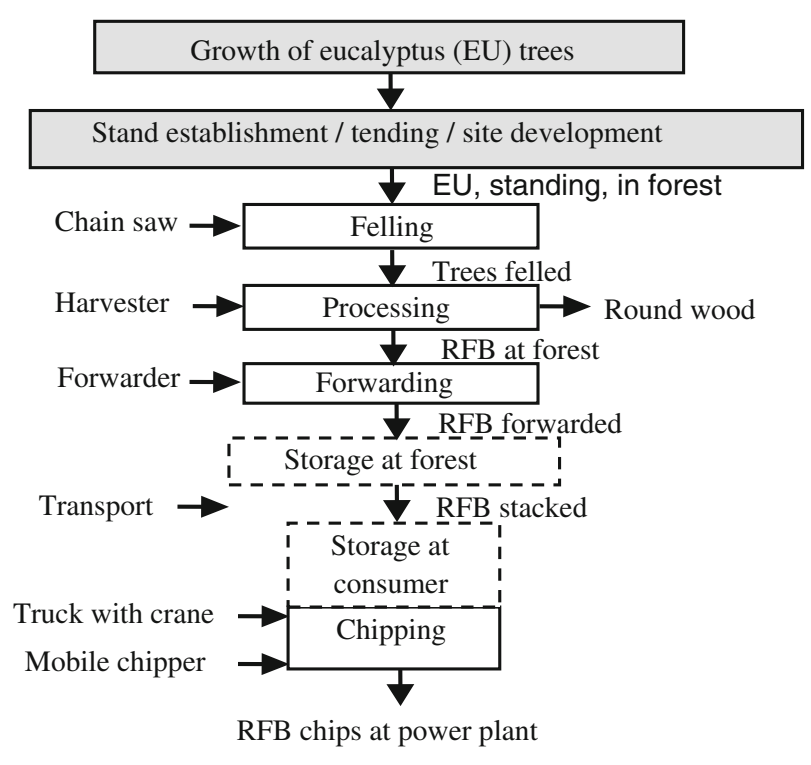

Fig. 2 Production chain of residual forest biomass (RFB) chips for energy

Goal and scope of the study

The main aim of this LCA study was to evaluate the environmental impacts of the eucalyptus RFB chips from cradle to the gate (from the forest to the power plant). The results are to be used by the companies to improve the environmental performance of the product and processes.

Description of the product

The eucalyptus RFB chips were provided from timber exploitation in the central region of Portugal and burned in a power plant.

\section{Boundaries}

The system boundaries are represented in a simplified way in Fig. 2. The processes included in the system boundaries were: Growth of eucalyptus (EU) trees; Stand establishment/tending/site development; Felling; Processing; Forwarding; and Chipping. The output of the processes (Growth of eucalyptus (EU) trees and Stand establishment/ tending/site development) is EU, standing, in forest. Processing of the trees is a multi-output process that produces RFB and round wood. The allocation of the environmental loads to two co-products was based on economic value.

\section{Data type/data collection}

The data related to processes were based on the data from a previous study performed by the authors (shaded processes in Fig. 2) [14] and by CBE [7] (remaining processes).
The most important data from the CBE study for this work are presented in Table 1 . The tree felling operation with hand-held chainsaws was studied in 7 parcels with an average production of $11 \mathrm{ton} / \mathrm{h}(=3,037.6$ ton trees felled/ 275.5 h spent).

Processing (removing the limbs and tops from the trees) with a harvester was carried out in five parcels with an average production of $12.8 \mathrm{ton} / \mathrm{h}(=1,833.3$ ton trees processed/143.1 h spent) (round wood + RFB).

The RFB forwarding (to the forest road) process with a forwarder was studied in seven parcels at an average of 8.1 ton/h $(=479.4$ ton RFB forwarded/59 h spent).

A total of 678.3 ton of RFB was transported (42 trips) by tractor with trailer with an average of 16.2 ton/trip $(=678.3$ ton RFB transported/42 trips) and an average apparent density (bulk density) of $172 \mathrm{~kg} / \mathrm{m}^{3}$. The RFB was transported, from the forest to the power plant, with an average distance of $38 \mathrm{~km}$.

After felling and processing the trees, the weighted average humidity of the RFB was $50 \%$ (moisture content-m.c. $100 \%$ ) and the RFB transported had a weighted average humidity of $22.6 \%$ (m.c. $29 \%$ ) with a minimum of $12 \%$ (in the summer months) and a maximum of $55 \%$ (winter months). The moisture content (mc) was calculated by $\mathrm{mc}=$ humidity/(1-humidity).

Other inventory data for the background system (such as Mobile Chipper work) were obtained from databases as recorded in Table 2 [9, 15-17].

\section{Functional unit}

The functional unit chosen was 1 ton (dry matter) of RFB chips at the power plant.

\section{Life cycle impact assessment (LCIA)}

The inventory analysis and, subsequently, the impact analysis were performed using the SimaPro7.3.3 LCA software and associated databases and methods [18]. EcoIndicator (99) H/A [19] was the method chosen for the impact assessment since this is commonly used and provides similar results to several other methods. This method is based on the so-called damage-oriented (end-point) approach. Its aim is to evaluate environmental consequences with reference to wider areas of concern, such as human health, ecosystem quality and resources.

\section{Normalization}

The quantified impact was compared to a certain reference value - the average environmental impact of a European citizen in 1 year. 
Table 1 Inventory data for the RFB chips production processes (taken from [7])

\begin{tabular}{|c|c|c|c|c|c|c|}
\hline \multirow[t]{2}{*}{ Process } & \multicolumn{3}{|l|}{ Inputs } & \multicolumn{3}{|l|}{ Outputs } \\
\hline & Name & Value & Units & Name & Value & Units \\
\hline \multirow[t]{2}{*}{ Felling } & Tree & $3,037.6$ & ton & Tree felled & $3,037.6$ & ton \\
\hline & Chain saw & 275.5 & $\mathrm{~h}$ & & & \\
\hline \multirow[t]{3}{*}{ Processing } & Tree felled & $1,833.3$ & ton & Round wood & $1,500.1$ & ton \\
\hline & Harvester & 143.1 & $\mathrm{~h}$ & RFB at forest & 177.9 & ton \\
\hline & & & & (RFB not recovered) & (155.3) & ton \\
\hline \multirow[t]{2}{*}{ Forwarding } & RFB at forest & 479.4 & ton & RFB, stacked & 479.4 & ton \\
\hline & Forwarder & 59 & $\mathrm{~h}$ & & & \\
\hline \multirow[t]{3}{*}{ Chipping } & RFB & 17 & ton & RFB chips & 17 & ton \\
\hline & Truck with crane & 1 & $\mathrm{~h}$ & & & \\
\hline & Mobile chipper & 1 & $\mathrm{~h}$ & & & \\
\hline
\end{tabular}

Table 2 Inventory data for the background system

\begin{tabular}{|c|c|c|}
\hline Process & Equivalent process & Source \\
\hline Mobile chipper & $\begin{array}{l}\text { Wood chopping, mobile } \\
\text { chopper, in forest }\end{array}$ & $\begin{array}{l}\text { Ecoinvent } \\
\text { database [9] }\end{array}$ \\
\hline Chain saw & $\begin{array}{l}\text { Power sawing, without } \\
\text { catalytic converter }\end{array}$ & $\begin{array}{l}\text { Ecoinvent } \\
\text { database [15] }\end{array}$ \\
\hline Transport & $\begin{array}{l}\text { Articulated lorry } \\
\text { transport }\end{array}$ & ELCD database [16] \\
\hline Harvester & $\begin{array}{l}\text { Delimbing, slide boom } \\
\text { delimber/RNA }\end{array}$ & USLCI [17] \\
\hline Forwarder & $\begin{array}{l}\text { Loader operation, large, } \\
\text { INW/RNA }\end{array}$ & USLCI [17] \\
\hline Truck with crane & $\begin{array}{l}\text { Loader operation, large, } \\
\text { INW/RNA }\end{array}$ & USLCI [17] \\
\hline
\end{tabular}

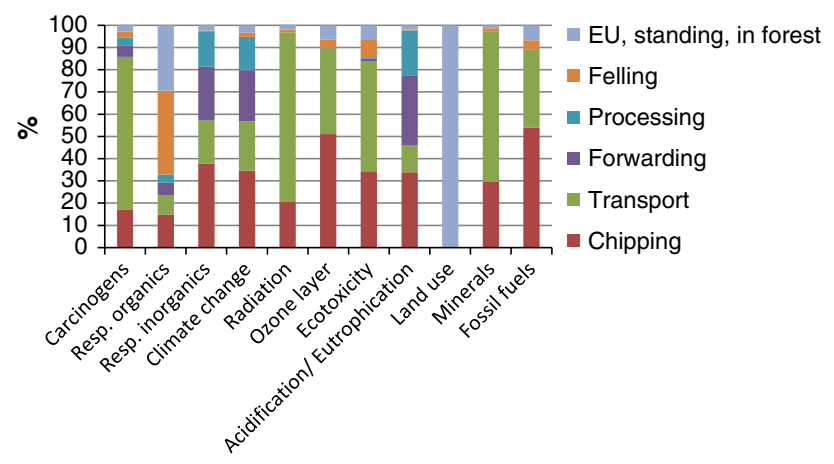

Fig. 3 Damage assessment of 1 ton of RFB chips at a power plant (impact categories)

\section{Results}

The Life Cycle Impact Assessment (LCIA) results of 1 ton (dry matter) of RFB chips at the power plant using the Ecoindicator 99 (H) V2.09/Europe EI 99 H/A/Damage Assessment method are presented in Figs. 3 and 4, respectively.

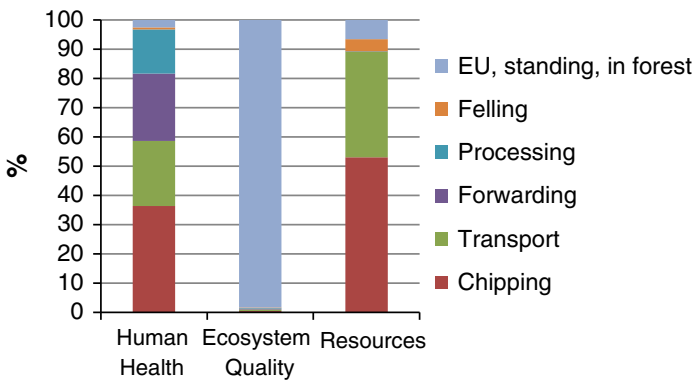

Fig. 4 Damage assessment of 1 ton of RFB chips at a power plant (damage categories)

The transport of RFB from the forest to the power plant "Transport" is the process which most contributes to the following impact categories (Fig. 3): "Carcinogens" (69\%) mainly due to emissions of arsenic into the water and cadmium into the water, soil and air; "Radiation" (76\%) mainly due to emissions of radon-222 and carbon14 into the air; "Ecotoxicity" (50\%) mainly due to emissions of chromium, zinc and nickel into the air; and "Minerals" (68\%) mainly due to nickel, aluminum and copper in the raw material. This process either contributes significantly to the "Ozone layer" (39\%), "Fossil fuels" (35\%), "Climate change" (22\%) and "Respiratory inorganics" (19\%). From Fig. 4, this is the second and the third most important process for "Resources" (36\%) and "Human Health" (22\%) damage categories, respectively.

The chipping of RFB with a mobile chipper "Chipping" is the process which most contributes to the following impact categories (Fig. 3): "Respiratory inorganics" (38\%) mainly due to emissions of particulates and nitrogen oxides into the air; "Climate change" (35\%) mainly due to emissions of carbon dioxide (fossil) into the air; "Ozone layer" (51\%) mainly due to emissions of Halon1301 into the air; "Acidification/eutrophication" (34\%) mainly due to emissions of nitrogen oxides into the air; and 


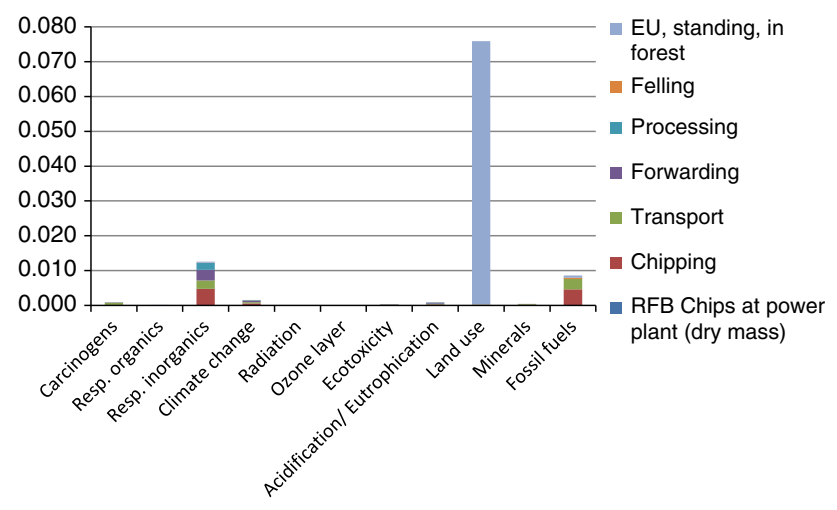

Fig. 5 Analyzing 1 ton of RFB chips at a power plant (normalization impact categories)

"Fossil fuels" (52\%) mainly due to the use of crude oil as raw material. This is also the process which most contributes to the "Resources" (53\%) and "Human Health (36\%) damage categories (Fig. 4).

The processing of the trees with a harvester "Processing" presents a moderate contribution for the "Acidification/eutrophication" (20\%) mainly due to emissions of nitrogen oxides into the air, "Climate change" (15\%) mainly due to emissions of carbon dioxide (fossil) into the air and "Respiratory inorganics" (16\%) mainly due to emissions of nitrogen oxide into the air.

The forwarding operation with a forwarder "Forwarding" is the second process that most contributes to "Respiratory inorganics" (24\%) mainly due to emissions of nitrogen oxides into the air, "Climate change" (23\%) mainly due to emissions of carbon dioxide (fossil) into the air and "Acidification/eutrophication" (31\%) mainly due to emissions of nitrogen oxides into the air.

The felling of trees with a chain saw "Felling" only presents a significant contribution (38\%) for "Respiratory organics" mainly due to emissions of non-methane volatile organic compounds into the air.

In terms of damage categories (Fig. 4), both "Processing" and "Forwarding" processes present a moderate contribution (15 and $23 \%$, respectively) to "Human Health" and are negligible with regard to the other categories.

The "Land use" impact category (Fig. 3) and the "Ecosystem Quality" damage category (Fig. 4) are almost exclusively (99.5 and $98 \%$, respectively) due to the processes included in "Eucalyptus (EU) standing in the forest".

The results of normalizing the impact categories for the European level (Fig. 5) show that "Land use" is the most significant impact category with 0.0759 European equivalents followed by "Respiratory inorganics" and "Fossil fuels" with 0.013 and 0.0086 , respectively. The remaining impact categories have a reduced contribution to the

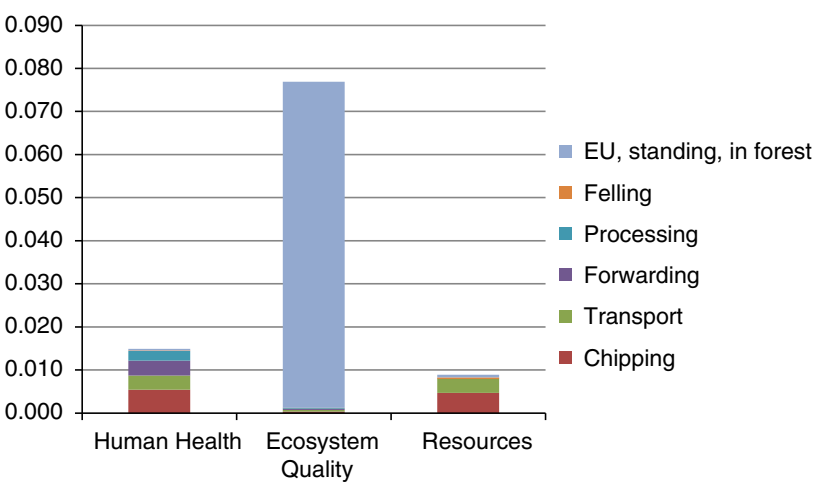

Fig. 6 Analyzing 1 ton of RFB chips at a power plant (normalization damage categories)

overall environmental impact of the functional unit. The results of normalizing the damage categories (Fig. 6) show that "Ecosystem quality" is the most representative damage category, corresponding to 0.077 European equivalents, followed by "Human health" and "Resources" with 0.015 and 0.0089 , respectively.

\section{Discussion}

In relation to the purposes of this study, the operations that are part of the exploitation chain and first transformation of RFB for energy purposes and that show the greatest potential to contribute to the environmental improvement of the product are those that contribute the most to "Land use" (see Fig. 5). This is, the operations related to "EU, standing, in forest", that is "Growth of eucalyptus trees" and "Stand establishment/tending/site development" (see Fig. 2). This can be achieved through the sustained increase in productivity of eucalyptus stands and/or reducing the area occupied by the forest paths. The contribution of these processes to the emissions and resource depletion is, however, negligible (see Fig. 3).

The operations that reveal the greatest potential for environmental improvement taking into account a reduction of emissions and depletion of energy resources are (in order of importance) (see Figs. 3, 5): the chipping of RFB "Chipping", that represents $38 \%$ of the impacts in "Respiratory inorganics" and $52 \%$ in "Fossil fuels"; the transportation by truck and trailer of RFB from the forest to the power plant "Transport", that represents $19 \%$ in "Respiratory inorganics" and $35 \%$ in "Fossil fuels"; the transport of RFB to forest road by forwarder "Forwarding" which contributes with $24 \%$ to "Respiratory inorganics"; the processing of trees felled by harvester "Processing" which represents $16 \%$ in "Respiratory inorganics"; and finally the felling of trees by chain saw "Felling" contributing $4 \%$ for "Fossil fuels". 
Taking into account the results of the study done by the Biomass Center for Energy [7], the average costs (and respective weight in total cost) of exploration operations and first transformation of the RFB were, in order of importance, the following (€/ton): $\quad$ Transport $=11.4$ $(35 \%)$; Chipping = $8.8(27 \%)$; Processing $=5.7(18 \%)$; Forwarding $=4.7(15 \%)$; and Felling $=1.5(5 \%)$.

In economic terms (cost), the operation that presents the greatest potential for reduction of the total cost is "Transport" followed by "Chipping" and "Processing", while in environmental terms the operation with higher potential for the reduction of overall impacts is "Chipping" followed by "Transport" and "Forwarding".

The processes that present the greatest potential for the reduction of greenhouse gas emissions are in order of importance the "Chipping", representing $35 \%$ of "Climate change" followed by "Forwarding" that represents $23 \%$ and "Transport" which represents $22 \%$ of that impact category. A sensitivity analysis on the potential consequences for the "Climate change" of the increase from 38 to $50 \mathrm{~km}(+32 \%)$ in the transport distance of $\mathrm{RFB}$, from the forest to the power plant, showed that this would cause an increase in this impact category of $8 \%$.

\section{Conclusions}

The processes that show the greatest potential for environmental improvement along the product life cycle (RFB chips) are those related to "Eucalyptus (EU) standing in the forest", that is, "Growth of eucalyptus trees" and "Stand establishment/tending/site development".

In terms of emissions and depletion of energy resources, the operation with the greatest potential for the reduction of global environmental impact is chipping of the RFB in the chipper followed by the transport of the RFB from the forest to the power plant by truck and trailer and the transport of RFB to forest road by forwarder. These three operations are responsible for approximately $81 \%$ on "Respiratory inorganics" and $87 \%$ on "Fossil fuels" which are the two most significant impact categories according to the data of the normalized environmental profile.

In contrast, in economic terms (cost), the operation that presents the greatest potential for reduction of the total cost is the "Transport" followed by "Chipping" and "Processing". These three operations are responsible for approximately $80 \%$ on total costs.

A sensitivity analysis showed that a $32 \%$ increase in the transport distance from the forest to the power plant would cause an $8 \%$ increase in "Climate change".
Acknowledgments The authors would like to thank the Portuguese Foundation for Science and Technology (FCT) through the PEst-OE/ CED/UI4016/2011 project, and the Center for Studies in Education, Technologies and Health (CI\&DETS) for their financial support of this study.

Conflict of interest The authors declare that they have no competing interests.

Author's contributions J.V.F.-LCA study and analysis. H.V.forestry operations study and analysis. B.E. and L.P.V.-inventory data for the background system. I.D.- paper revision.

Open Access This article is distributed under the terms of the Creative Commons Attribution License which permits any use, distribution, and reproduction in any medium, provided the original author(s) and the source are credited.

\section{References}

1. Directive 2009/28/EC of the European Parliament and of the Council of 23 April 2009 on the promotion of the use of energy from renewable sources and amending and subsequently repealing Directives 2001/77/EC and 2003/30/EC

2. Directorate General for Energy and Geology (DGEG): Renewable, rapid statistics (in Portuguese), $\mathrm{n}^{\circ}$ 103, September 2013

3. Institute for Nature Conservation and Forestry (ICNF): IFN6, Land use areas and forest species of Portugal. Preliminary results (in Portuguese), pp. 34, Lisboa (2013)

4. Netto, C: Potential of residual forest biomass for energy purposes of three municipalities in the district of Santarém (in Portuguese). Dissertation, New University of Lisbon (2008)

5. National Directorate of Forestry Ranks: Forestry Energy CropsFirst Approach Survey of the Current Situation (in Portuguese). http://www.icnf.pt/portal/florestas/fileiras/biomassa-solid/resource/ docs/biomassa-texto-gtce-junho-2010-v30-06-2010 (2010). Accessed 10 Jan 2013

6. Campilho, P: Quantification of biomass from the forestry sector with potential use for bioenergy sector (in Portuguese). Working report, Instituto Superior de Agronomia, Universidade Técnica de Lisboa (2006)

7. Biomass Center For Energy (CBE): Optimization of Forestry Operations, Collection, Packaging, Transport and Primary Transformation of Waste for Energy Production (in Portuguese), Miranda do Corvo (2004)

8. U.S. Environmental Protection Agency and Science Applications International Corporation: LCAccess-LCA 101. http://www. epa.gov/ORD/NRMRL/lcaccess/lca101.htm (2001). Accessed 22 January 2013

9. Werner, F., Althaus, H., Kunninger, T., Richter, K., Jungbluth, N.: Life Cycle Inventories of Wood as Fuel and Construction Material. Ecoinvent report No 9, EMPA Duebendorf Swiss Centre for Life Cycle Inventories, Dubendorf, CH (2007)

10. Berg, S., Lindholm, E.L.: Energy use and environmental impacts of forest operations in Sweden. J. Clean. Prod. 13, 33-42 (2005)

11. Michelsen, O., Solli, C., Strømman, A.H.: Environmental impacts and added value in forestry operations in Norway. J. Ind. Ecol. 120(1), 69-81 (2008)

12. International Standard Organisation (ISO) (eds): Environmental management-Life cycle assessment-ISO 14040 (2006); ISO 14044 (2006)

13. Wegener, A., Van Oers, L.F.C.M., Guinée, J.B., Struijs, J., Huijbregts, M.A.J.: Normalisation in product life cycle assessment: 
an LCA of the global and European economic systems in the year 2000. Sci. Total Environ. 390, 227-240 (2008)

14. Ferreira, J., Domingos, I.: Life cycle inventory of Hardwood (Eucaliptus) production in the Portuguese forest. In: Proceeding of the Abstracts of the Ecowood 5th International Conference on Environmentally-Compatible Forest Products, Fernando Pessoa University, Porto, Portugal, 5-7 September 2012

15. Kellenberger, D., Althaus, H., Kunninger, T., Jungbluth, N., Lehmann, M., Thalmann, P.: Life cycle inventories of building products. Ecoinvent report No 7, EMPA Duebendorf Swiss Centre for Life Cycle Inventories, Dubendorf, CH (2007)

16. PE INTERNATIONAL. ELCD database 2.0. Articulated lorry Transport; Euro 0, 1, 2, 3, $4 \mathrm{mix}$; $40 \mathrm{t}$ total weight, $27 \mathrm{t}$ max payload. http://elcd.jrc.ec.europa.eu/ELCD3/resource/processes/ b444f4d0-3393-11dd-bd11-0800200c9a66?format=html\&version= 03.00.000. Accessed 19 Jan 2013

17. National Renewable Energy Laboratory. US Life Cycle Inventory Database (USLCI). https://www.lcacommons.gov/nrel/search (2012). Accessed 20 Jan 2013

18. PRé Consultants: Introduction to LCA with SimaPro 7, Report version: 4.5.http://www.pre-sustainability.com/download/man uals/SimaPro7IntroductionToLCA.pdf (2010). Accessed 10 Jan 2013

19. PRé Consultants: SimaPro Database Manual—Methods library, Report version: 2.4. http://www.pre-sustainability.com/down load/DatabaseManualMethods_oct2010.pdf (2010). Accessed 10 Jan 2013 